Marquette University

e-Publications@Marquette

Philosophy Faculty Research and Publications

Philosophy, Department of

$10-1-2006$

\title{
Restorative Justice and Reparations
}

Margaret Urban Walker

Marquette University, margaret.walker@marquette.edu

Accepted version. Journal of Social Philosophy, Vol. 37, No. 3, (Fall 2006): 377-395. DOI. (C 2006

Wiley. This article may be used for non-commercial purposes in accordance With Wiley Terms and Conditions for self-archiving.

Margaret Urban Walker was affiliated with Arizona State University at the time of publication. 


\title{
Restorative Justice and Reparations
}

\author{
Margaret Urban Walker \\ School of Historical, Philosophical and Religious Studies, Arizona \\ State University \\ Tempe, $A Z$
}

In her book Between Vengeance and Forgiveness, Martha Minow begins a chapter on reparations with a brief discussion of restorative justice. She characterizes restorative justice as seeking "repair of social connections and peace rather than retribution against offenders;" she describes it as "building connections and enhancing communication between perpetrators and those they victimized, and forging ties across the community..." ${ }^{1}$ Later in the same chapter, however, when talking about monetary reparations Minow says the "core idea" behind reparations is compensatory justice, the view that "wrongdoers should pay victims for losses" to wipe the slate clean. ${ }^{2}$

Several recent discussions of reparations for historical injustice and mass political violence reject the idea that compensatory or, as I will call it, corrective justice is the relevant or primary category for reparations involving groups or large numbers of individual victims of injustice. ${ }^{3}$ Roy Brooks considers the "tort model" of pursuing compensation from institutions and private parties through legal action a secondary, morally deficient and relatively unpromising avenue. He advances an "atonement model" of reparations premised on "the postHolocaust vision of heightened morality, victim-perpetrator identity, egalitarianism, and restorative justice. ${ }^{\prime 4}$ Although Brooks does not define restorative justice, his account of atonement makes apology central and sees monetary and other reparations as necessary to make apologies believable. Janna Thompson situates her argument for historical obligations to repair past wrongs, such as the theft of lands from indigenous people or the injustice of slavery, in a conception of "reparation as reconciliation" in contrast to a "legalistic" one of "reparation as restoration." The aim of reparations on this view is "to repair relations damaged by injustice-not to return to a state of affairs that existed before the injustice was done."

Journal of Social Philosphy, Vol. 37, No. 3 (Fall 2006): pg. 377-395. DOI. This article is (C) Wiley and permission has been granted for this version to appear in e-Publications@Marquette. Wiley does not grant permission for this article to be further copied/distributed or hosted elsewhere without the express permission from Wiley. 
Ruti Teitel, in her extensive study of transitional justice practice, finds that "reparatory practices have become the leading response in the contemporary wave of political transformation," but that reparatory practices in political transition "defy categorization as either criminal or corrective justice" by both redressing individual rights violations and signifying responsibility for criminal wrongdoing. ${ }^{6}$ Naomi Roht-Arriaza appeals to "a basic maxim of law that harms should be remedied" in a discussion of reparations for mass violence, but argues that individual court-ordered reparations are both impractical in cases where there are many victims and inadequate to address collective elements of harm in situations of mass conflict or repression where communities are targeted for violence and are sometimes made complicit in atrocities. ${ }^{7}$ She advocates collective reparations, like community development, community participatory adjudication or preferential access to services, while recognizing that such collective measures may fail adequately to address or protect victims of political violence. Discussing cases of mass violence and repression, Pablo de Greiff makes the most extensive and pointed argument against a "juridical" approach to reparations that aims to re-establish the status quo ante by proportionate compensation for harms. Compensating for harms on this legalistic conception entails problems of quantification and generalization of harms, as well as interpersonal comparisons of suffering, creating divisive hierarchies of victims and clouding the relationship of reparations programs to other justice measures. He proposes an expressly "political" conception of reparations programs that measures their effectiveness in terms of social justice; reparations programs should express and create conditions for recognition, civic trust, and social solidarity between victims and others in societies undergoing political transition. ${ }^{8}$

The field of application for reparations is broad, comprising cases where wrongs are discretely episodic and the concrete means of repair (for example, monetary compensation) are fairly straightforward, cases of gross and murderous violation of massive numbers of human beings during a specific period of political repression or persecution, and group histories of destruction, dispossession, subjugation and degradation of status that span centuries. The nature and background of particular cases of injury, as well as the foreground of current social relationships and practical political possibilities, matter decisively for how injury and responsibility

Journal of Social Philosphy, Vol. 37, No. 3 (Fall 2006): pg. 377-395. DOI. This article is (C) Wiley and permission has been granted for this version to appear in e-Publications@Marquette. Wiley does not grant permission for this article to be further copied/distributed or hosted elsewhere without the express permission from Wiley. 
are apt to be understood, and what measures of repair are apt to be available and meaningful. I do not wish to deny that what many writers call a "legalistic" or "juridical" understanding of reparationsbasically, reparation as an exercise of corrective justice-might be usefully applied in some cases. Nor do I attempt to draw a single line of demarcation between cases where corrective justice will serve adequately as a model for reparation and those to which it is wholly inapt. I propose to explore an alternative to corrective justice as a framework for reparations in certain kinds of cases.

Although there is no consensus on even a formal characterization of corrective justice, conceptions of corrective justice as a moral ideal suppose a moral baseline of acceptable conduct or due care and regard for the security, dignity or well-being of others. Corrective justice demands "correction" of what are presumed to be discrete lapses from that prior or standing moral baseline in particular interpersonal or institutional transactions with individuals, or unacceptable impacts of the action or omission of some individuals upon others. ${ }^{9}$ For this reason, corrective justice may be at least artificial and perhaps incoherent in addressing histories, acts or forms of injustice that consists in radical denial of moral standing or in relentless enforcement of degraded moral status of individuals, especially when these are systemic conditions and persist over extended periods of time. Conditions of moral exclusion and degradation, typically embodied either in legal exclusion from certain standings, the absence of political rights or the enforcement of diminished political and civil status, are invariably based on group membership defined either by putatively natural or elective attributes (race, gender, ethnicity, religious creed, disability, sexuality) or by proscribed political activity or membership. These conditions may endure for centuries (histories of dispossession and cultural and physical destruction visited on indigenous people by European colonization) or be relatively transient (political persecutions under particular regimes).

The "problem of the baseline" is not adequately comprehended by corrective justice. Rather, I will argue, it is the construction of morally adequate relations in and through the establishment of defensible and shared moral baselines that is a requirement of justice in certain cases, along with reparation for the manifold effects of the

Journal of Social Philosphy, Vol. 37, No. 3 (Fall 2006): pg. 377-395. DOl. This article is (C) Wiley and permission has been granted for this version to appear in e-Publications@Marquette. Wiley does not grant permission for this article to be further copied/distributed or hosted elsewhere without the express permission from Wiley. 
absence or unacceptability of such baselines and the usually repetitive failure to recognize, admit, or correct. Restorative justice, I will argue, is a more adequate framing ideal for reparative practice where there is a need to establish a governing understanding of "right relationship" and to approach its realization, rather than to intervene episodically to correct deviations from an existing standard. I will explore some ways that restorative justice is more instructive concerning what injuries of denial and degradation involve, and so what it means to address and redress them, as well as whose responsibility it might be to do so. I will argue that restorative justice accommodates and perhaps requires bottom-up and incremental attempts at repair as a social and political process, a process that may be signified but is not exhausted by a particular reparations program or reparative gesture like a public apology. I identify six core values of restorative justice and explain its guiding aim of "restoring relationships." I examine a distinctive orientation within restorative justice to compensation as one among many means to repair, to articulating wrongs and harms fully, to processes that "leverage" responsibility, and to the active role of communities of varying types in doing justice. The case I address briefly in conclusion is that of African-American reparations.

\section{Corrective Justice and the Moral Baseline}

Critics of a corrective justice model of reparations - whether they call it "legalistic," "compensatory," "juridical," or "reparatory" find conceptual, practical, political and moral grounds for criticism. Conceptually, it is fair to say, as de Greiff does, that corrective justice tends to focus on mechanisms of restitution or compensation and to emphasize some representative relationship, usually "proportionality," between compensation and injury. It is not easy to pry corrective justice thinking away from legal paradigms of compensating for undue loss and injury, although often compensation in political or historical cases is apt to be, and perhaps in the interests of political feasibility and social solidarity must be, symbolic. Practically, dealing with compensation for very large numbers of victims of political violence or oppression poses financial burdens and political snares in many transitional contexts where reparations compete for limited resources. Administrative arrangements for implementing reparations mechanisms can become costly, divisive and demoralizing if they are

Journal of Social Philosphy, Vol. 37, No. 3 (Fall 2006): pg. 377-395. DOl. This article is (C) Wiley and permission has been granted for this version to appear in e-Publications@Marquette. Wiley does not grant permission for this article to be further copied/distributed or hosted elsewhere without the express permission from Wiley. 
too fine-grained in vetting eligibility. In some cases, like histories of chattel slavery, sexual enslavement or genocide, the meaning of compensation is powerfully shaped by the larger frame: other gestures of recognition, acknowledgment, atonement, memorializing, social support and guarantees of prevention determine whether financial compensation sends an acceptable and dignifying message to victims and perpetrators, as well as to society generally. It may often be these other nonmonetary measures that are possible, valuable, and necessary, whether or not monetary compensation is likely or wise. Reparations policies must be politically feasible, but neither can they appear as cheap buy-outs or fail to address victims directly and to validate their experience of suffering and specific experience of injustice, lest they add further moral insult to moral and material injury. The balance of individual and collective reparative measures, and delicate matters of fit among monetary, service, and rehabilitation packages and more symbolic gestures, can seem to outstrip the rather basic idea of a "give back" that has dominated corrective justice thinking since Aristotle. These problems are real and pressing but they might be understood as symptoms of a deeper issue. The framework of corrective justice strains, because it has never been meant to deal with either a massive scale of serious mayhem or a protracted and brutal subjugation and mutually ramifying indignities and atrocities that characterize oppressive and violently repressive systems. But what is the "framework of corrective justice"?

There is no canonical formal characterization of the kind of justice that sets right wrongful or undue losses and injuries any more than there is a single accepted terminology. Some writers emphasize a right to reasonable security from undue losses imposed even by others' nonculpable acts while others delimit the occasions for corrective justice to cases of wrongdoing or the violation of rights. ${ }^{10}$ Some see corrective justice as a remedial mechanism to restore just distributions, while others see corrective justice as more autonomous and directed to maintaining a basis for stable expectations that facilitate social cooperation in various interactions, at least to some extent independently of the justice of underlying distributions. ${ }^{11} \mathrm{~A}$ common function of corrective justice in numerous accounts, however, is that there is a standard of moral acceptability for the impact we have on each other through our actions and interactions, and that corrective justice responds to correct those impacts of action and 
interaction that fall outside of that standard of moral acceptability, however it is characterized. This is the standard I call the moral baseline, and it may be set in terms of just distribution, a kind of right or rights, a norm of fairness, standards of due care and attentiveness, or the dignity and respect-worthiness of persons.

Unsurprisingly, contemporary authors are inclined to characterize the moral baseline of corrective justice in the language of moral equality. Gerald Gaus describes compensatory justice as aiming at restoration of "moral equality." ${ }^{12}$ Bernard Boxill's early piece on black reparations sees justice as requiring equal consideration between equals, and so an acknowledgment of the error of treatment that fails to respect equality and a reaffirmation of belief in equality of the injured party. ${ }^{13}$ It seems possible, however, for corrective justice to function as a principle in societies with differentiated and even hierarchically organized statuses with reciprocal but not symmetrical obligations and responsibilities; there, too, there will be due and undue treatment and recognition, and so a need for redressing interactions and impacts that deprive some parties of what they rightfully claim. Hammurabi's laws, for example, include many specific rules not only for punishing prohibited acts but also for correcting transactions involving slaves and masters, husbands and wives, parents and children, who are not supposed to enjoy equality of status in the modern sense.

There is, then, a duality within corrective justice. Its moral function might be described as defining and preserving reciprocity and responsibility between individuals (or groups) for their actions and impacts on each other in certain respects (identified by particular norms) in a social order defining proper places and allowing stable interpersonal expectations. ${ }^{14}$ Yet the norms that set the baselines for acceptable treatment and due care and attention that give corrective justice its specific content - what actions or impacts it is a requirement of justice to correct, and what reparative actions will constitute correction - may themselves be morally indefensible; at the extreme, an assumption of reciprocity may be absent. When norms define unequal statuses based on bogus forms of innate superiority, fabricated natural hierarchies of authority or natural divisions of talent and interest, or when they opportunistically deny rights or effective protection and remedies to powerless, despised or stigmatized groups,

Journal of Social Philosphy, Vol. 37, No. 3 (Fall 2006): pg. 377-395. DOI. This article is (C) Wiley and permission has been granted for this version to appear in e-Publications@Marquette. Wiley does not grant permission for this article to be further copied/distributed or hosted elsewhere without the express permission from Wiley. 
then indefensible moral baselines of corrective justice, or the absence of moral baselines with respect to members of some despised group, becomes part of that for which justice requires a remedy. Corrective justice is only as morally legitimate as the baselines it treats as morally compelling. The legitimacy of baselines becomes an issue in cases of gross or systemic mistreatment or deprivation of rights characteristic of oppressive social structures and, in somewhat different ways, in political episodes where states, often with some legal basis ("emergency powers"), terrorize or mistreat segments of their own population. Societies over time may come to adopt more justifiable baselines that move toward more uniform recognition of equal worth and dignity of all members. This recognition of equal dignity sets the stage for addressing the problem of faulty baselines that both license unjust treatment and are a cause of it. It does not, however, solve this problem, although measures that acknowledge precisely that situation we might expect to be part of what corrective justice demands.

Corrective justice uses its moral baseline to identify and attach obligations of repair to faulty performance under the standards, not to faulty standards. Furthermore, corrective justice, if it is to be a basis for reparations, requires principles that can span cultural and national communities. While international and humanitarian law and evolving best practices purport to set a universal standard of moral equality, it is an aspirational standard that does not and in many instances cannot define stable expectations for those whose more local communities and cultures, legal and social, play by very different rules. Thus, the framework of corrective justice seems to predicate the normal operation of legitimate standards of conduct and impact in order to secure performance or repair for failure in, or untoward outcomes due to, the performance of actors. It is not accidental that one analysis that clearly identifies the problem of the baseline is Andrew Sharp's study of the search for justice between Maori and Pakeha people of New Zealand. Sharp adopts a legalistic conception of restitution and compensation, but incorporates not only the idea of "reciprocal exchange between two equal parties" in his definition of reparative justice, but also the proviso that the parties recognize "the same standards of right." 15 Sharp's focus on justice claims in an intercultural, historical and post-colonization context brings the problem of a shared baseline to the fore. It is also one reason for 
Sharp's sobering conclusion that "in conditions of biculturalism, strict justice is actually impossible."16

Strict justice may well be impossible in any case of gross violence or systemic degradation, yet the question of how best to conceive the measure of justice remains. Discussions of reparation continue to invoke the ideal of corrective (or compensatory or reparative) justice, which in turn is pulled inevitably toward legal models of responsibility to compensate for wrongful harm. The basic idea of "compensating" for harm is stretched in various practical, symbolic or moral directions, or is assimilated to the compensatory framework by referring to the "remedies" and "satisfaction" due to victims of serious wrong, staying with the fundamental idea of "giving back" in order to set right. ${ }^{17}$ Given the limitations of the framework of corrective justice, I explore the potential of another, less philosophically familiar picture of justice.

\section{Restorative Justice: A Conception and its Values}

Restorative justice is not yet part of the shared philosophical language of justice theory. Nor does restorative justice sit easily with the priority of "ideal theory" that has controlled much thinking about justice in the late twentieth century. Ideal theory was identified by Rawls as the necessary starting point of justice theory. Ideal theory assumes a "well-ordered society" in which "everyone is presumed to act justly and to do his part in upholding just institutions." 18 Within the Rawlsian framework compensatory justice is essentially part of "partial compliance theory" that deals with injustice. Restorative justice begins from and defines itself in terms of the reality of violation, alienation, and disregard among human beings. Its central concept of "restoring relationships" supposes that it is disregard or violation of acceptable human relationships that stands at the core of its agenda, practically and philosophically.

Restorative justice was introduced to many for the first time when it was invoked as the guiding conception of South Africa's Truth and Reconciliation Commission. ${ }^{19}$ The theory and practice of restorative justice, however, began two decades earlier in criminal justice applications with experiments such as victim-offender mediation programs and forms of family or community conferences. I

Journal of Social Philosphy, Vol. 37, No. 3 (Fall 2006): pg. 377-395. DOl. This article is (C) Wiley and permission has been granted for this version to appear in e-Publications@Marquette. Wiley does not grant permission for this article to be further copied/distributed or hosted elsewhere without the express permission from Wiley. 
suggest that six central restorative justice values repeat throughout an extensive and growing literature. ${ }^{20}$

1. Restorative justice aims above all to repair the harm caused by wrong, crime, and violence.

2. Restorative justice makes central the experiences and needs (material, emotional, and moral) of victims.

3. Restorative justice insists on genuine accountability and responsibility-taking from those who are responsible for harm, ideally directly to those who have suffered the harm.

4. Restorative justice seeks to return ownership of the resolution of wrong, crime, and harm to those primarily affected and those who can in turn effect meaningful repair: to those who have done wrong or are responsible for harm, to victims, to immediate communities of care of victims and offenders, and to larger affected or interested communities.

5. Restorative justice aims at offering those responsible for wrong and harm the opportunity through accountability and repair to earn self-respect and to be reintegrated without stigma into their communities.

6. Restorative justice seeks to build and strengthen individuals' and communities' capacities to do justice actively, and not to surrender the role of doing justice to experts, professionals, or "the state," which should play facilitating roles.

These core values serve the ultimate aim and guiding norm of restorative justice, "restoring relationships." In restorative justice what demands repair is a state of relationship between a victim and wrongdoer, and among each and his or her community that has been distorted, damaged or destroyed. Serious harm to individuals creates a relationship charged with powerful negative feelings and burdened with losses that can continue to mar a victim's life. Restorative justice targets a situation of negative connection or disconnection that might be an ongoing source of threat, insult, anger, fear, and grief. ${ }^{21}$ It is not always possible, nor is it always desirable, to restore relationship between those who have done or allowed harm and those who have suffered at their hands or by their indifference or carelessness. In some cases where restoration between victims and offending persons

Journal of Social Philosphy, Vol. 37, No. 3 (Fall 2006): pg. 377-395. DOI. This article is @ Wiley and permission has been granted for this version to appear in e-Publications@Marquette. Wiley does not grant permission for this article to be further copied/distributed or hosted elsewhere without the express permission from Wiley. 
is possible it can nevertheless mean only a wary coexistence. In any case, however, it is necessary to attempt to restore morally habitable conditions for those wronged within their supporting network of relationships and in their communities. At a minimum, others must acknowledge the wrong and harm done to victims and accept the legitimacy of victims' demands for recognition and redress. Where some bear responsibility (in any of several ways) for the wrong done to others, apology, combining acknowledgment of wrong, responsibility for wrong and repudiation of wrong, is in order. ${ }^{22}$ Resentment of victims' claims to repair, victim-blaming or indifference to a victim's violation and suffering is the antithesis of restoration: it tells the victim that the wrong is denied or that he or she does not matter.

The terminology of "restoration" is sometimes criticized because it implies return to a condition of relationship that either did not exist or was unacceptable. ${ }^{23}$ I propose that we understand "restoration" in all contexts as normative: "restoration" refers to repairs that move relationships in the direction of becoming morally adequate, without assuming a morally adequate status quo ante. Morally adequate relations are ones in which three conditions obtain. In them, people are confident that they share some basic standards for the treatment of each other. People are able to trust each other to abide by those standards or at least to acknowledge fault if they (or others) do not abide by them. And so, finally, people are entitled to be hopeful that unacceptable treatment will not prevail, that unacceptable behavior will not be defended or ignored where it occurs, and that victims will not be abandoned in their reliance on our shared commitment to our standards and to each other. ${ }^{24}$

The ideal of restorative justice is that its values should be expressed both in the structure of processes of dealing with violence and injustice and in the outcomes of doing so. Paradigmatic restorative justices practices, such as victim-offender dialogue, group conferences, truth commissions, or apologies (personal or public), not only aim at adequate forms of relationship as an outcome but require participants to act out the morally adequate relationships at which they aim. The practices involve responsive and respectful forms of encounter, interaction, and expression, such as offenders directly facing and hearing victims; victims being able to confront offenders 
and to seek information directly from offenders about what happened and why they were targeted, information that is often critical to victims' own understanding, peace of mind, and sense of blamelessness. Offenders, too, are able to represent themselves, and in doing so may be able to represent their own human vulnerabilities and their regret or shame as well as their willingness to apologize and make amends, affirming their competence and self-respect as moral agents. In some formats other participants encourage more honest, responsive, and responsible interaction between victim and offender, and they can exert pressure as well as provide support for plans of restitution, compensation, or service that aim at repair.

A corrective justice framework tends to make compensation making good a victim's loss - central, with pressures toward defining a metric of loss and, ideally, compensation in some proportion to loss. There are familiar challenges for this approach, including the obscurity of counterfactual claims about what victims "would have" had, and puzzles about how much of what they might have had they now deserve to receive. ${ }^{25}$ Many serious harms and injustices, such as the murder of a loved one or the expropriation of a people's land and destruction of their language and culture due to genocidal practices of colonization, create losses that are not literally compensable at all. Restorative justice, too, emphasizes material and practical amends that address victims' losses and needs, but restitution and compensation in a restorative framework play instrumental and symbolic roles in repairing relationships, including the role of adding weight to expressive interpersonal gestures such as apology and expressions of sorrow, shame, guilt or desire to relieve the victims' pain and anger. The direct concern of restorative justice is the moral quality of future relations between those who have done, allowed, or benefitted from wrong and those harmed, deprived or insulted by it. In some cases compensation or restitution will be indispensable to signify full recognition, respect and concern to victims. In other contexts material reparation might be unnecessary, and in no cases is it, by itself, sufficient for signaling appropriate moral regard. Compensation by itself need not signal responsibility for injury, much less regret or atonement by those responsible. Without a surrounding framework of respectful acknowledgment, responsibility and concern, compensation can take on insulting, condescending or dismissive meanings. The nature and meaning of restitution or compensation in restorative 
justice should emerge from a practice of communication centered on the needs and understandings of victims as well as wrongdoers' deepened understanding of the nature and meaning of the victims' loss and of the nature and extent of their own responsibility.

A second difference between restorative justice and corrective justice approaches concerns the common phenomenon of denial, evasion, or minimizing of responsibility by those implicated in wrongdoing. Corrective justice, like retributive justice, requires that responsibility of particular parties be established in order to determine who must or should "pay" for wrong, through punishment or compensation. Ironically, this almost guarantees that the "bigger" the injustice the more contested will be the antecedent premises of responsibility. The more massive, collectively supported or tolerated, or historically extended an injustice is, the easier it will be to argue that assignments of responsibility are unclear, incoherent or unfair, and so that arguments for large-scale redress cannot get started, or measures of redress are narrowly targeted to a few parties.

Restorative justice practices by contrast typically create the conditions to leverage responsibility, that is, to move people from a minimal or peripheral sense of connection and responsibility to a richer and more demanding perception of what harms the wrong does and how they might be related to it.

In restorative justice practices that address ordinary crime, such as victim-offender mediation, conferences, or peacemaking circles, once offenders and other responsible or concerned parties are willing to engage in restorative justice practice, it is common for this movement toward greater and broader acceptance of responsibility to occur. Those who have already assumed some responsibility come to a deepened sense of the reality, extent and consequences of what they have done to another human being. It is also common for others concerned, such as families or communities, to begin to see themselves as implicated, either by connections they have not before examined or admitted, or by a realization that they can make a difference by contributing to or assisting with some form of repair. Victims along with others may want to take an active role in the restorative outcome or in a continuing process of repair. Restorative practice is thus dynamic with respect to responsibility. It may not be necessary to establish responsibility extensively, exclusively or 
certainly in order to engage in restorative justice; restorative justice practice may be the a way to discover, induce, deepen, extend, and clarify responsibilities that are unnoticed, resisted or denied at the outset of a process, or have been reassuringly assigned to some small number of target individuals. Institutional, governmental, and community exercises in restorative justice, including projects of finding and telling truths, create the opportunity and the medium for apparent responsibilities to be acknowledged, but also for additional responsibilities, both backward and forward looking, to be discerned and accepted. ${ }^{26}$

A third feature of restorative justice lies in its fostering a full exploration of the nature and impact of the wrong and of the rupture in relationship that explains it or results from it. Communicative interaction and voice for victims, whether in the form of a face to face conference or in the form of an official truth process after political violence, aims to create an adequate description of the wrong which is essential to assessing the requirements of repair. Trudy Govier points to research that shows a substantial "magnitude gap" between victims and perpetrators (and sometimes, we might note, between either and third parties) in evaluating the seriousness of harms. ${ }^{27}$ As injustices grow in magnitude, violence, and historical duration the reality, nature, intent and seriousness of violations becomes predictably contested, and the need for a careful and detailed articulation of the full story of violence, oppression, terror or subjugation becomes both a reparative activity and a measure of the adequacy of other measures of repair.

Finally, restorative justice makes communities of varying sizes and descriptions central in several ways. Communities may be harmed, materially and morally, by wrongs to their members and to their resources, including their moral resources of trust and hopefulness. Communities can also serve as actors or as guarantors of repair and restoration of relationships. When individuals primarily responsible for wrongs and harms are unavailable or are unwilling to accept responsibility and to seek to redress their wrongs, restoration may devolve to communities or networks within communities. Indeed, the emphasis in restorative justice on catalyzing and strengthening the capacity of individuals and communities to do justice in the wake of wrongdoing suggests that official actors in the legal system or 
government are by no means the only actors and should not always be the principal actors in attempting to bring justice to bear. Restorative justice encourages "bottom-up" efforts at justice, while not excluding official roles or responsibilities. Restorative justice supports not a zerosum but a "both-and" approach to responsibility for restoration of relations.

The idea of "community" is used very flexibly in restorative justice, but there is a practical basis for allowing the identification of the relevant community in context. The harmed community and the community that can effectively respond to support repair need not be the same collectivity. It might be that neither community possesses an organizational structure and executive function to undertake actions corporately and representatively; the relevant collectivities might be relatively unstructured or informal, like a locality or neighborhood. The community that can effectively respond need not do so, or even be able to do so, corporately; it might be that its members or some groups of members act out of it, or on its behalf, or in its name. And there might also be multiple responsible communities, some institutionally embodied and represented, and others not, that can and should play roles in addressing and redressing injustice. In some restorative justices practices in the criminal context, like forms of conferencing or peacemaking circles, the community or communities can encompass individuals and groups that see themselves as harmed by the crime, others that have reason for concern, and others still who are potential sources of support and guarantee of plans for repair in which they themselves might or might not participate. In a restorative justice perspective, communities that matter can be multiple and differently situated with respect to a crime or injustice. Relevant communities might not be given in advance but rather formed in response to the demands of doing justice in the wake of specific wrongs. ${ }^{28}$

\section{Black Redress and a Restorative Justice Perspective}

I want to illustrate very briefly the productive nature of a restorative justice perspective for one kind of case where a shared moral baseline has never been firmly and reliably in effect. The case is

Journal of Social Philosphy, Vol. 37, No. 3 (Fall 2006): pg. 377-395. DOI. This article is (C) Wiley and permission has been granted for this version to appear in e-Publications@Marquette. Wiley does not grant permission for this article to be further copied/distributed or hosted elsewhere without the express permission from Wiley. 
the failure of "black redress," to use Roy Brooks's succinct phrase for the need in the United States to address and redress several hundred years of enslavement, legal subjugation and exclusion and legally tolerated exposure to violence extending from the seventeenth to the mid-twentieth century. This history of injustice arguably continues today in society's acquiescence in persisting and repeatedly documented inequalities of wealth, health, freedom, civic respect and life-prospects for African-Americans, and in widespread resistance to and resentment of the topic of reparations for slavery and its sequels in the general - majority white - public. I do not undertake here to repeat the history of cruel and profound injustice punctuated by opportunities and failures to repair that others have ably provided. ${ }^{29}$ What I add here is that restorative justice identifies the problem and the path to reparation in a way better suited to this kind of case than does the corrective model.

Restorative justice targets the damage or distortion in relationship that is both a cause and an effect of wrongs. A problem that lies at the heart of the continuous and continuing sequence of enslavement, legal subjugation and persisting exposure to violence, discrimination and neglect of enslaved Africans in America and AfricanAmerican citizens is the profound distortion of relationship, socially and emotionally, between the still rigid and polarized raced groups, "black" and "white," that are constituted by this very distortion. A deep and unexamined contempt of whites for blacks is the most salient and disturbing symptom of the distortion. The attitude of contempt ranges from the benign contempt of indifference to the history, current condition and future of African-Americans to the angry contempt of defensive hostility and overt racism of many whites toward blacks, especially when asked to pay attention to the history or present conditions of injustice. Focusing on white attitudes to blacks, however, is both incomplete and deceptive; the legacy of race and white supremacist racism also decisively shapes the self-understanding of whites. The contempt of indifference allows whites not to feel that they are part of an urgent present problem and allows whites to be illinformed and uncurious, or complacently but often mistakenly confident, in what they know about the history and legacies of racial oppression. It allows whites to think of the history of race in America as something that happened to African-Americans and not what happened to whites. Part of the self-understanding of whites, as 
decades of critical race theory reveals, is not to know what whiteness means; to think that race and racial oppression has to do with blacks and other non-white people; and to feel right-minded in condemning unconscionable things that were done to African-Americans "long ago," even though legally enforced segregation is within the memory of many living individuals who have never received reparation. ${ }^{30}$ For African-Americans, the basis for earned trust in whites is lacking; worse, its emergence is undermined by continuing evidence of racism and the persistence of the denial or minimization of the reality of racism still common in white America, as well as indifference or hostility to appeals for reparation that reappear punctually throughout American history from slavery times. ${ }^{31}$ Deeper lies the assault on the hopefulness of many African-Americans who face reduced life chances and the reality that their children may for another generation contend with the insults and obstacles of racism, and the results of poverty, poor education, crime and incarceration, that others blithely ignore or deny. ${ }^{32}$

A telling symptom of a disconnected, evasive or hostile attitude of white Americans to the unredressed history of injustice to AfricanAmericans is reported opposition among white Americans toward a U.S. government apology for slavery or that larger history. Polls continue to show heavy white opposition to - and black support for an official national apology for slavery. ${ }^{33}$ Apology is the most minimal but unambiguous and foundational gesture of repair. Not to apologize is to fail to accept, and refusal to apologize is to deny, the fact of the wrong, the seriousness of the wrong, responsibility for the wrong, repudiation of the wrong, or all of these. ${ }^{34}$ Official apologies, furthermore, not only acknowledge and accept responsibility for a past wrong, but typically serve to signal a recognized need to re-establish institutional moral credibility, an intent to establish a certain version of events as the official story, and a public resolve to accept a correct moral standard for future conduct. ${ }^{35}$ To resist an official apology reveals opposition to this definitive public correction of course. Another dimension of apology, often crucial to its effect but not always adequately noted, is the empathetic function of apology. Apologies are often inadequate or disappointing to the one harmed if they do not manage to convey appreciation of the suffering, anger, mistrust or grief the victim experiences as a result of the wrong. ${ }^{36}$ To refuse

Journal of Social Philosphy, Vol. 37, No. 3 (Fall 2006): pg. 377-395. DOl. This article is (C) Wiley and permission has been granted for this version to appear in e-Publications@Marquette. Wiley does not grant permission for this article to be further copied/distributed or hosted elsewhere without the express permission from Wiley. 
apology can mean refusing to acknowledge that these universal human responses to injury and disrespect are fitting.

There are compelling arguments for responsibility of the U.S. government as a continuing institution that bears responsibility for its roles in accepting and protecting slavery and then in legitimating the degraded Jim Crow citizenship that currently living individuals and communities have endured. ${ }^{37} \mathrm{I}$ agree that the federal government is an appropriate and important locus of responsibility for apology and further reparative measures. Yet restorative justice, while not rejecting the importance of moral responsibilities of government, offers a distinctive perspective: justice is done both in and by restoring moral relationship and so affirming, perhaps for the first time, a truly shared moral baseline of reciprocal responsibility and equal dignity. Governmental actions alone are not adequate to that task, and government action on more local - state and municipal - levels might represent in a more immediate way communities with which people identify, especially if those communities address their own local histories of racial violence, exploitation or exclusion. Institutions like corporations, churches and universities are other localities for the identification and exploration of unredressed racial wrongs.

At the same time, the "restoration of relationship" sought within restorative justice terms, pursued on local levels by governmental, institutional and civic initiatives, could create better conditions for the pursuit of national reparations, material and symbolic, for AfricanAmericans. Putting a priority on historical inquiry, dialogue and voice of those concerned or affected, and inviting active engagement in the present with the past, opens opportunities that restorative justice distinctively seeks. There can be fuller articulation of wrongs, discovery of their consequences and space for acknowledgment of responsibilities of various kinds, including past involvement or acquiescence in unacceptable practices, recognition of benefits from racial inequality, irresponsible or defensive ignorance of facts, or the ability to contribute to changing the future. Legacies of racial violence and oppression will predictably have affected African-Americans in immediate ways (including incidents of violence and victimization that may have remained unknown in families and communities) but may also have affected whites and other racial minorities negatively. Past cooperative efforts across racial lines might also come into focus

Journal of Social Philosphy, Vol. 37, No. 3 (Fall 2006): pg. 377-395. DOI. This article is (C) Wiley and permission has been granted for this version to appear in e-Publications@Marquette. Wiley does not grant permission for this article to be further copied/distributed or hosted elsewhere without the express permission from Wiley. 
alongside practices that used race to stigmatize and humiliate citizens. Local initiatives can explore forms of reparation - memorials, celebrations, history projects, museums, educational programs, genealogy projects, public art, dramatic performance, and others that meaningfully address the nature of wrongs and moments of constructive change in particular communities whose identities and boundaries might be reconfigured by such initiatives.

\section{Conclusion: Untangling Relations and Incubating Reparations}

I have described restorative justice as an approach to reparations that could be adopted, but I was prompted to think about the restorative justice and reparations by reflecting on an actual surge in local initiatives to deal with unredressed racial injustice and violence against African-Americans in the past ten to fifteen years.

The Greensboro Truth and Reconciliation Commission, America's first self-named truth commission, is a privately financed project to examine the 1979 shootings of five anti-racist community activists by Klansmen and neo-Nazis that will release its final report in May, 2006. A 500-page report released in 2005 was commissioned by the General Assembly of North Carolina to explore the overthrow by whites of the government of the town of Wilmington, ending black participation in local government until the civil rights era. The state of Florida passed a compensation program in 1994 for survivors of a white race riot that destroyed the town of Rosewood in 1923. An investigation of the Tulsa Race Riot of 1921 in which whites destroyed the prosperous black community of Greenwood published its report in 2002, recommending reparations for survivors and descendants; reparations have so far not been enacted. The state of Virginia recently matched private funds to provide scholarships for state residents who were unable to continue their education when Prince Edward County and other locales shut down public schools in the 1950s rather than desegregate them. Several cities, including Chicago, Philadelphia and Los Angeles, have passed ordinances requiring disclosure of links to slavery by corporations receiving municipal business. Charleston, South Carolina, is preparing to open the Old Slave Mart Museum in an original building where slave auctions were held until 1863. In 2001, on the occasion of the university's 300th anniversary, three doctoral candidates at Yale

Journal of Social Philosphy, Vol. 37, No. 3 (Fall 2006): pg. 377-395. DOI. This article is (C) Wiley and permission has been granted for this version to appear in e-Publications@Marquette. Wiley does not grant permission for this article to be further copied/distributed or hosted elsewhere without the express permission from Wiley. 
University researched Yale's use of slave-trade money and choices to honor slave-traders and defenders of slavery in the naming of its colleges. Ruth Simmons, Brown University's first African-American president, formed a University Steering Committee on Slavery and Justice in 2003 to research Brown's historical ties to slavery. Prosecutors have reopened notorious civil rights era murder cases in which indictments or convictions were impossible to secure at the time, in what are appropriately named "atonement trials," while states have begun to consider mass or individual pardons for thousands of people who violated segregation laws or were convicted due to racial bias.

These developments might be seen as fragmentary justice or alternative remedies where justice has failed. I suggest we see them instead as multiple, local initiatives that might be better understood under the rubric of restorative justice. These initiatives arise from or address communities and institutions, in some cases through government and law and in others through the effort or the leadership of individuals. They aim to address victims or descendants, to acknowledge buried or unredressed injustices, to create accountability, to offer gestures or repair, to respond to the needs of living victims and to memorialize victims who are beyond the reach of justice. Placed within the framework of restorative justice, these efforts are parts of a decentralized and incremental work of restoration and reparation that seems fitted to the historical length, breadth and complexity of the injustice in question. These actions might also build momentum toward the passage of Representative John Conyers' H.R. 40 proposal for a national commission to examine the history and effects of slavery and its sequels to the present day, to explore ways to educate the American public and to study the question of reparations, itself a measure in the spirit of restorative justice, inviting public dialogue and seeking a fuller accounting of wrongs.

Whether or not a national apology or reparations are achieved in the near or the longer term, diverse and dispersed initiatives at different levels are particularly fitting in a case of deeply distorted relations, mystifying and incomplete histories, and transgenerationally entrenched alienation within and between groups. A striking model for what is needed in such a case is provided in Manu Meyer's discussion of ho'oponopono, a traditional Hawaiian peacemaking practice that 
addresses troubled family relations. The practice aims at "examining one layer at a time, of inching toward the source of trouble to untangle emotion, actions, and motivations, which will, in turn, uncover yet another, deeper layer of the same."38 It requires a clear view of the problem and a disciplined and guided work of "untangling" thoughts and emotions that stand between people and in the way of understanding and addressing the wrong or conflict. Could there really be a shortcut through a process like this, given centuries of distorted and violent racialized relations in the United States?

I have argued that restorative justice provides a more adequate way to conceptualize injustice and its compounding causes and effects over generations in a case such as the relationship between white Americans and African-Americans. Restorative justice outlines a more varied menu of mutually supporting ways of addressing such injustice than does corrective justice as usually understood. My brief for the superiority of restorative justice as an approach to reparations in certain cases, however, need not be seen as completely excluding the relevance of corrective justice. Conceptually, corrective justice might be seen as a limit case of restorative justice where there has been a local violation of a standing norm in the context of mutually authoritative standards; in fact, the theory of restorative justice has been developed largely within a criminal justice context as a way to address victims' rights to a direct and constructive response of accountability and repair from offenders who have harmed them in a particular criminal act. Practically, corrective justice and its idea of compensation as an expression of responsibility may well be one effective and familiar (and effective because familiar) concrete format for signifying and sealing between parties an understanding of right relationship, or a decisive step in the direction of such an understanding, that had been lacking previously. Symbolically, corrective justice may convey counterfactually the "restoration" of what should have existed but in reality did not previously obtain. This symbolism - of equal parties settling a debt required by their reciprocal recognition under shared norms - might be particularly apt at a certain point in cases where reparation, including acknowledgments of and apologies for a history of varied and gross mistreatment, comes very late: after a brutally oppressed, viciously stigmatized and persistently disadvantaged group has survived and struggled its way to recent formal equality, as is true of African-

Journal of Social Philosphy, Vol. 37, No. 3 (Fall 2006): pg. 377-395. DOI. This article is @ Wiley and permission has been granted for this version to appear in e-Publications@Marquette. Wiley does not grant permission for this article to be further copied/distributed or hosted elsewhere without the express permission from Wiley. 
NOT THE PUBLISHED VERSION; this is the author's final, peer-reviewed manuscript. The published version may be accessed by following the link in the citation at the bottom of the page.

Americans. In order to perform this symbolic function, however, it will likely have to consolidate a more varied and complex process of historical accounting, acknowledgment, cultivating trust and making amends for which restorative justice provides the rationale. ${ }^{39}$

\section{Notes}

1. Martha Minow, Between Vengeance and Forgiveness (Boston: Beacon Press, 1998), 92.

2. Minow, Between Vengeance and Forgiveness, 104.

3. The systematic treatment of reparations has only recently emerged as a philosophical topic and there is no uniform terminology for the species of justice that imposes obligations to repair wrongful losses; writers speak variously of compensatory justice, corrective justice, reparative justice, reparatory justice and rectificatory justice. In contrast to the concept of "distributive justice," which is widely viewed as justice in the distribution of socially produced benefits and burdens, varied terminology surrounding justice in repair also reflects a lack of consensus about the moral function of corrective justice, whatever it may be called. I will use the terminology of "corrective" justice and return later to the question of how to characterize its basic moral function.

4. Roy L. Brooks, Atonement and Forgiveness: A New Model for Black Reparations (Berkeley and Los Angeles: University of California Press, 2004), xv, xvi, 11, 19, 141, 148, and 211.

5. Janna Thompson, Taking Responsibility for the Past: Reparation and Historical Injustice (Cambridge: Polity Press, 2002), xix).

6. Ruti Teitel, Transitional Justice (New York: Oxford University Press, 2000), 127-128.

7. Naomi Roht-Arriaza, "Reparations in the aftermath of repression and mass violence," in. My Neighbor, My Enemy: Justice and Community in theAftermath of Mass Atrocity, ed. Eric Stover and Harvey M. Weinstein (Cambridge: Cambridge University Press. 2004), 121-123.

8. Pablo de Greiff, "Justice and Reparations," in The Handbook of Reparations, ed. Pablo de Greiff (New York: Oxford University Press, 2006).

9. No doubt contemporary discussions of corrective or compensatory justice in the Anglo-American literature are heavily influenced by AngloAmerican legal practices concerning tort and contract. See the opening of Cass R. Sunstein, "The Limits of Compensatory Justice," in

Journal of Social Philosphy, Vol. 37, No. 3 (Fall 2006): pg. 377-395. DOI. This article is (C) Wiley and permission has been granted for this version to appear in e-Publications@Marquette. Wiley does not grant permission for this article to be further copied/distributed or hosted elsewhere without the express permission from Wiley. 
Compensatory Justice, ed. John W. Chapman (New York and London: New York University Press, 1991) on "five basic principles" of compensatory justice in this legal tradition.

10. On a right to security of person or possession from lapses of care, even if not culpable, as the moral basis of corrective justice, see D. N. MacCormick, "The Obligation of Reparation," Proceedings of the Aristotelian Society 78 (1977-78): 175-194; on corrective (or "rectificatory") justice as applying to violations of rights, see Rodney Roberts, "Justice and Rectification: A Taxonomy of Justice," in Injustice and Rectification, ed. Rodney Roberts (New York: Peter Lang, 2002). Jules Coleman considers nonculpable infringement of rights as well as culpable rights violation and other wrongdoing as requiring recognition of the victims' loss and the worthiness of repair, in Coleman, "Corrective Justice and Property Rights," also in Roberts, Injustice and Rectification.

11. James W. Nickel, "Justice in Compensation," William and Mary Law Review 18 No. 2 (1976): 379-388, considers the purpose of compensatory justice the protection of just distribution by both preventing and undoing acts that disturb such distributions. It is fair to say that corrective justice is more typically not seen as reducible to, or essentially a means to, just distributions.

12. Gerald F. Gaus, "Does Compensation Restore Equality?" in Roberts, Injustice and Rectification, 93-94.

13. Bernard Boxill, "The Morality of Reparation," in Roberts, Injustice and Rectification, 128. Aristotle's original account of corrective justice in Nichomachean Ethics 1132 "treats the parties as equal" in rectifying unjust gains and losses between parties even when, in Aristotle's hierarchical view of human worth, they clearly are not so.

14. See Coleman, "Corrective Justice and Property Rights," on the "local" character of corrective justice that "has to do with the baseline or background norms governing wrongdoing within a particular community, and with 'local understandings' of more general norms," 61.

15. Andrew Sharp, Justice and the Maori (Auckland: Oxford University Press, 1997), 34.

16. Sharp, Justice and the Maori, 23.

17. Current standards for reparations are defined by the United Nations Commission on Human Rights, "Revised Set of Basic Principles and Guidelines on the Right to Reparation for Victims of Gross Violations of

Journal of Social Philosphy, Vol. 37, No. 3 (Fall 2006): pg. 377-395. DOI. This article is (C) Wiley and permission has been granted for this version to appear in e-Publications@Marquette. Wiley does not grant permission for this article to be further copied/distributed or hosted elsewhere without the express permission from Wiley. 
NOT THE PUBLISHED VERSION; this is the author's final, peer-reviewed manuscript. The published version may be accessed by following the link in the citation at the bottom of the page.

Human Rights and Humanitarian Law / prepared by Theo van Boven pursuant to sub-commission decision 1995/117," United Nations Document E/CN.4/Sub.2/1996/17.

18. John Rawls, The Theory of Justice (Cambridge, Mass: The Belknap Press, 1971), 8.

19. South Africa's Truth and Reconciliation Commission said restorative justice: seeks to redefine crime from offence against the state to any injury to and violation of particular human beings; is based on reparation as the healing and restoration of victims, offenders, families and the larger community; encourages all stakeholders to be directly involved in resolving conflict, with the state and legal profession in facilitating roles; and aims at offender accountability and full participation of victims and offenders in putting things right. See Truth and Reconciliation Commission of South Africa Report (London: Palgrave Macmillan, 1999) Volume 1, Chapter 5, "Concepts and Principles," paragraph 82. Essays in Robert I. Rotberg and Dennis Thompson, Truth v. Justice: The Morality of Truth Commissions (Princeton: Princeton University Press, 2000) discuss restorative justice in the TRC.

20. Sources include Howard Zehr, Changing Lenses: A New Focus for Crime and Justice (Scottsdale, Pa.: Herald Press, 1995); Dennis Sullivan and Larry Tifft, Restorative Justice: Healing the Foundations of our Everyday Lives (Monsey, N. Y.: Willow Tree Press, 2001); Gordon Bazemore and Mara Schiff, eds. Restorative Community Justice: Repairing Harm and Transforming Communities (Cincinnati: Anderson Publishing, 2001); Heather Strang and John Braithwaite, Restorative Justice and Civil Society (Cambridge: Cambridge University Press, 2001). John Braithwaite, Restorative Justice and Responsive Regulation is most comprehensive in its theoretical scope and review of empirical studies. Gerry Johnstone, A Restorative Justice Reader: Texts, sources, context (Portland, Oregon: Willan Publishing, 2003) provides a full overview of the field. A usefully brief summary discussion of current restorative justice practices is provided by Gordon Bazemore and Mark Umbreit, "A comparison of four restorative conferencing models," in Johnstone, A Restorative Justice Reader. A related literature on peacemaking with emphasis on traditional or adapted indigenous practices includes: Kay Pranis, Barry Stuart, and Mark Wedge, Peacemaking Circles: From Crime to Community (St. Paul, Minn.: Living Justice Press, 2003); Robert Yazzie, "'Life Comes From It,': Navajo Justice Concepts," New Mexico Law Review 24 No. 2 (1994): 175-190; Barbara E. Wall, "Navajo Conceptions of Justice in the Peacemaker Court," Journal of Social Philosophy 32 No. 4 (2001):

Journal of Social Philosphy, Vol. 37, No. 3 (Fall 2006): pg. 377-395. DOI. This article is (C) Wiley and permission has been granted for this version to appear in e-Publications@Marquette. Wiley does not grant permission for this article to be further copied/distributed or hosted elsewhere without the express permission from Wiley. 
NOT THE PUBLISHED VERSION; this is the author's final, peer-reviewed manuscript. The published version may be accessed by following the link in the citation at the bottom of the page.

532-546; and Manu Meyer, "To Set Right - Ho'oponopono: A Native Hawaiian Way of Peacemaking," The Compleat Lawyer 12 No. 4 (1995): 30-35.

21. On the complexity of victims' responses, and the predictable needs for voice, validation of the reality of their violation and suffering, and vindication in experiencing some form of proper redress, see Margaret Urban Walker, "The Cycle of Violence," Journal of Human Rights 5 No. 1 (2006): 1-25.

22. One recent account of varied forms of "accountability" for harms is Christopher Kutz, Complicity: Ethics and Law for a Collective Age (Cambridge: Cambridge University Press, 2000).

23. Harvey M. Weinstein and Eric Stover propose "reclamation" as a more fitting term for retrieving a social and moral situation from barbarity or disorder. See their "Introduction: conflict, justice, and reclamation," in My Neighbor, My Enemy: Justice and Community in the Aftermath of Mass Atrocity, ed. Eric Stover and Harvey M.Weinstein (Cambridge: Cambridge University Press, 2004), 15.

24. See my Moral Repair: Reconstructing Moral Relations After Wrongdoing (New York: Cambridge University Press, 2006) for a defense of these constitutive conditions of moral relationship.

25. Two discussions that explore these problems in cases of long-running and still continuing historical injustices are George Sher, "Ancient Wrongs and Modern Rights," Philosophy and Public Affairs 10 No. 1 (1980): 317, and Jeremy Waldron, "Superseding Historic Injustice," Ethics 103 No. 1 (1992): 4-28.

26. See Marc Forget, "Crime as Interpersonal Conflict: Reconciliation Between Victim and Offender," in Dilemmas of Reconciliation: Cases and Concepts, ed. Carol A. L. Prager and Trudy Govier, eds. (Waterloo, Ontario: Wilfrid Laurier University Press, 2003) on the dynamic quality of restorative justice.

27. Trudy Govier, Forgiveness and Revenge (London: Routledge, 2002), 128.

28. Paul McCold and Benjamin Wachtel refer to "micro-communities created by the incident of a crime" as the "means through which healing and re-integration is possible," in Paul McCold and Benjamin Wachtel, "Community is Not a Place: A New Look at Community Justice Initiatives," in Johnstone, A Restorative Justice Reader, 300. See also Howard Zehr, Changing Lenses: A New Focus for Crime and Justice (Scottsdale, PA: Herald Press, 1995) on the relation between restorative and community justice.

Journal of Social Philosphy, Vol. 37, No. 3 (Fall 2006): pg. 377-395. DOI. This article is (C) Wiley and permission has been granted for this version to appear in e-Publications@Marquette. Wiley does not grant permission for this article to be further copied/distributed or hosted elsewhere without the express permission from Wiley. 
NOT THE PUBLISHED VERSION; this is the author's final, peer-reviewed manuscript. The published version may be accessed by following the link in the citation at the bottom of the page.

29. See Brooks, Atonement and Forgiveness and Andrew Valls, "Racial Justice as Transitional Justice," Polity 36 No. 1 (2003): 53-71, on the continuity and failure to repair. Ronald P. Salzberger and Mary C. Turck, Reparations for Slavery: A Reader is a useful compendium of the repeated proposals for reparation and the issues raised. Robert Sparrow, "History and Collective Responsibility," Australasian Journal of Philosophy 78 No. 3 (2000): 346-359, presents a thoughtful and moving discussion of the historical continuity of injustice to Australia's Aboriginal people, with implications for historically continuous and continuing injustices to other groups.

30. Charles Mills, The Racial Contract (Ithaca: Cornell University Press, 1997) characterizes white racial consciousness as an "epistemology of ignorance."

31. Brooks, Atonement and Forgiveness, 4-19, provides a summary of this history. See also David Lyons, "Corrective Justice, Equal Opportunity, and the Legacy of Slavery and Jim Crow," Boston University Law Review 84 No. 5 (2004): 1375-1404. Danielle Allen's Talking to Strangers: Anxieties of Citizenship since Brown v. Board of Education (Chicago: University of Chicago, 2004) sees race relations in the U.S. as exposing a more general problem of "trust-generating citizenship" that is acute in the case of relations between black and white in America.

32. See Walker, Moral Repair, Chapter 6, for a fuller discussion of the structure of contempt.

33. Joe R. Feagin and Eileen O'Brien, "The Growing Movement for Reparations," in Roy Brooks, ed., When Sorry Isn't Enough: The Controversy Over Apologies and Reparations for Human Injustice (New York: New York University Press, 1999), cites a 1997 ABC News poll that reports two-third of white Americans resist the idea of an apology from the federal government for slavery, and 88 percent rejected reparations.. Ellis Cose, Bone to Pick: Of Forgiveness, Reconciliation, Reparation, and Revenge (New York: Atria Books, 2004), 171, reports a more recent September, 2003, poll finding 30 percent of whites (compared to 79 percent of blacks) believe blacks are due an apology for slavery, and four percent of whites were in favor of compensation for slavery, compared to 67 percent of blacks. The United States Senate, however, recently passed by voice vote an apology for failing to enact federal legislation against lynching decades ago. See Sheryl Gay Stolberg, "Senate Issues Apology Over Failure on Lynching Law," New York Times, 14 June 2005.

Journal of Social Philosphy, Vol. 37, No. 3 (Fall 2006): pg. 377-395. DOI. This article is (C) Wiley and permission has been granted for this version to appear in e-Publications@Marquette. Wiley does not grant permission for this article to be further copied/distributed or hosted elsewhere without the express permission from Wiley. 
NOT THE PUBLISHED VERSION; this is the author's final, peer-reviewed manuscript. The published version may be accessed by following the link in the citation at the bottom of the page.

34. A most helpful recent account of apology is Aaron Lazare, On Apology (New York: Oxford University Press, 2004). On official apology see also Trudy Govier and Wilhelm Verwoerd, "The Promise and Pitfalls of Apology," Journal of Social Philosophy 33 No. 1 (2002): 67-82.

35. Kathleen A. Gill, "The Moral Functions of an Apology," in Roberts, Injustice and Rectification, 119-122.

36. See Gill, "The Moral Functions," 114; Govier and Verwoerd, "The Promise and Pitfalls," 71; and Lazare, On Apology, 44.

37. Discussions include: Brooks, Atonement and Forgiveness; Robert Fullinwider, "The Case for Reparations," Report of the Institute for Philosophy and Public Policy 20 No. 2/3 (2000), in the University of Maryland Institute for Philosophy and Public Policy website, http://www.puaf.umd.edu/IPPP/reports/vol20sum00/case.html (accessed 8 April 2006), reprinted in Salzberger and Turck, Reparations for Slavery; and Rahul Kumar and David Silver, "The Legacy of Injustice: Wronging the Future, Responsibility for the Past," in Justice in Time: Responding to Historical Injustice, ed. Lukas $\mathrm{H}$. Meyer (Baden-Baden: Nomos Verlagsgesellschaft, 2004).

38. Meyer, "To Set Right - Ho'oponopono," 33.

Journal of Social Philosphy, Vol. 37, No. 3 (Fall 2006): pg. 377-395. DOI. This article is (C) Wiley and permission has been granted for this version to appear in e-Publications@Marquette. Wiley does not grant permission for this article to be further copied/distributed or hosted elsewhere without the express permission from Wiley 